\title{
The Effectiveness of Topical Mangosteen Pericarp Extract on the Collagen of Mice Skin Exposed to Ultraviolet B
}

\author{
Elfa Wirdani Fitri ${ }^{1,}$, , Anis Irawan Anwar ${ }^{1}$, Khairuddin Djawad ${ }^{1}$, Arifin Seweng ${ }^{2}$, \\ Husni Changara ${ }^{3}$, Gemini Alam ${ }^{4}$ \\ ${ }^{1}$ Department of Dermatovenereology, Faculty of Medicine, Hasanuddin University, Makassar, Indonesia \\ ${ }^{2}$ Department of Biostatistics, Faculty of Public Health, Hasanuddin University, Makassar, Indonesia \\ ${ }^{3}$ Department of Anatomical-Pathology, Faculty of Medicine, Hasanuddin University, Makassar, Indonesia \\ ${ }^{4}$ Department of Pharmacognosy, Faculty of Pharmacy, Hasanuddin University, Makassar, Indonesia
}

Email address:

gorgeous_elfa@yahoo.co.id (E.W. Fitri)

${ }^{*}$ Corresponding author

\section{To cite this article:}

Elfa Wirdani Fitri, Anis Irawan Anwar, Khairuddin Djawad, Arifin Seweng, Husni Changara, Gemini Alam. The Effectiveness of Topical Mangosteen Pericarp Extract on the Collagen of Mice Skin Exposed to Ultraviolet B. American Journal of Clinical and Experimental Medicine. Vol. 4, No. 3, 2016, pp. 88-93. doi: 10.11648/j.ajcem.20160403.19

Received: May 5, 2016; Accepted: May 23, 2016; Published: June 1, 2016

\begin{abstract}
Exposure to ultraviolet B (UVB) has an impact in the form of changes in the dermis collagen fibers and can result in decreasing the thickness and density of collagen. This study aims to assess the effectiveness of mangosteen pericarp extract to the thickness and density of collagen in mice skin after being exposed to UVB. This research was conducted in the animal laboratory and the anatomic pathology laboratory Hasanuddin University, Makassar. The study used pure animal experimental research design with control group. The samples were 24 mice that were divided into four groups: normal, UVB, ethanol and mangosteen groups. Mangosteen pericarp extract with a concentration of $50 \%$ was applied shortly after the mice were exposed to UVB. The thickness and density of collagen in normal group was significantly higher than UVB and ethanol groups. Mangosteen groups showed collagen density higher than UVB and ethanol groups. No significant differences between mangosteen and normal group. No significant differences between ethanol and UVB groups. Mangosteen pericarp extract with a concentration of $50 \%$ (2 mg / gBW mice) can increase the thickness and density of collagen in mice skin exposed to UVB.
\end{abstract}

Keywords: Collagen, Mangosteen Pericarp Extract, Mice Skin, Ultraviolet-B

\section{Background}

Sunlight is a source of electromagnetic energy which mainly consists of solar ultraviolet (UV), visible light and infrared radiation. The ability to reach the Earth were significantly affected by the atmosphere in its path so that only two-thirds of the earth's solar energy captured. [1]

Various effects of acute and chronic effects resulting from exposure to UV that causes sunburn, pigmentation, premature aging and skin cancer are found in the community. Although the data for these effects have not been published, but based on the geographical location, enables the high incidence of various cases in Indonesia, besides the Indonesian people live more in rural areas and worked as farmers and fishermen led to research on the strategy of handling the adverse effects of sunlight are very important. [2]

Collagen is one of the dominant component fibers in the dermis layer of the skin. Collagen fibers contribute to the strength, integrity and structure of skin. In the event of damage to the dermis due to exposure to UV, there was a change in the form of a reduction of collagen fibers and results in a decrease in collagen density. [3] It is due to exposure to UVB due to the effects of free radicals, which cause damage at the cellular level and ultimately result in cell death of collagen and fibroblasts that produce collagen. $[3,4]$

To prevent the cellular damage associated with oxidative stress, it is important to maintain the balance of oxidants with antioxidants, and this can be performed with antioxidant supplementation. [5] One Indonesian plant that can be used 
for such purposes is the mangosteen fruit (Garcinia mangostana), especially the use of the fruit skin. Mangosteens come from tropical forests in Southeast Asia, such Indonesia. Mangosteen pericarp oxidises clear resin that is rich in xanthones. [6] Mangostin is a major Xanthone derivative, and is present in mangosteen. In the mangosteen pericarp extract is found Xanthone content of $95 \%$, besides it also contains isoflavones, tannins and flavonoids. [7]

Based on these literature survey above, it is necessary to do a study to assess the effectiveness of mangosteen pericarp extract to the thickness and density of collagen in mice skin after being exposed to UVB.

\section{Material \& Method}

The study used a pure animal experimental research design with control group. It was conducted in the animal laboratory and the anatomic pathology laboratory of Hasanuddin University, Makassar, from January to February 2016. after obtaining the approval from ethics committee of Health Research.

The samples were 24 mice that meet the criteria. The criteria for inclusion were species of Swiss albino mice, aged 6-9 weeks, weight 20-30 g, female gender and healthy. Exclusion criteria were the mice were sick and dying during the study. The samples that met the criteria were divided into 4 groups: normal, UVB, ethanol and mangosteen groups.

Mangosteen pericarp extract with a concentration of 50\% was made in the laboratory of Pharmacognosy phytochemical, Faculty of Pharmacy, Hasanuddin University. Each treatment was given mangosteen pericarp extract as much as 3 drops $(0.1 \mathrm{ml})$ is equivalent to a dose of $2 \mathrm{mg} /$ gBW mice.

UVB radiation in mice using a $311 \mathrm{~nm}$ narrow band UVB (Dermalight 1000) with the power of $450 \mathrm{~mJ} / \mathrm{cm}^{2}$ three times a week for 4 weeks.

Histopathological preparations obtained from skin tissue of mice backs by excisional biopsy. Each specimen was fixed with buffered formalin, then placed on a flat surface and cut into two parts. Making a slide taken from pieces of tissue in the middle, which is cut perpendicular to the thickness of 4 $\mu \mathrm{M}$ then was staining using Masson's Trichrome staining for collagen assessment.

Collagen thickness was measured by taking the average thickness of the bottom edge of the basement membrane to the upper edge of the subcutaneous fat tissue are marked in green by masson's trichrome staining. Results 5 field of view with a magnification of $100 \mathrm{x}$ in print on $\mathrm{A} 4$ paper with a size of $100 \%$, and its thickness is measured using a ruler in centimeters $(\mathrm{cm})$ on each field of view. Measurements were performed by 3 assessors.

The density of collagen fibers was performed using a light microscope with a magnification of 400x. Each sample rated by 3 assessors. To assess the density of collagen fibers used criteria:

(-) Or 0: do not look the collagen fibers

$(+)$ Or 1: collagen fibers look very thin or slightly
$(++)$ Or 2: the collagen fibers spread very thin or slightly $(+++)$ Or 3: Collagen fibers being spread $(++++)$ Or 4: Collagen fibers spread solid.

The data obtained were analysed through the Statistical Product And Service Solutions (SPSS). The analysis is comparing the scores density and thickness of collagen in all four groups. The statistical test used was Kruskal-Wallis. Significant test results if the test $p$-value $<0.05$. If the above test is significant, advanced test (post-hoc test) to assess which groups are different. Post-hoc test method used is the Bonferroni method.

\section{Result}

\subsection{Collagen Thickness}

There are significant differences in the thickness of the collagen in the sample group $(\mathrm{p}<0.001)$ (Table $1 \&$ Figure 1)

Table 1. Comparison of Collagen Thickness $(n=24)$.

\begin{tabular}{lllllll}
\hline Group & Minimum & Maximum & Mean & Median & SD & p \\
\hline Normal & 6,00 & 9,73 & 6,97 & 6,53 & 1,41 & \\
UVB & 3,00 & 4,67 & 3,78 & 3,67 & 0,80 & \\
Etanol & 2,63 & 4,50 & 3,33 & 3,05 & 0,77 & 0,000 \\
Manggis & 5,27 & 8,87 & 6,77 & 6,68 & 1,30 & \\
\hline
\end{tabular}

Kruskal-Wallis

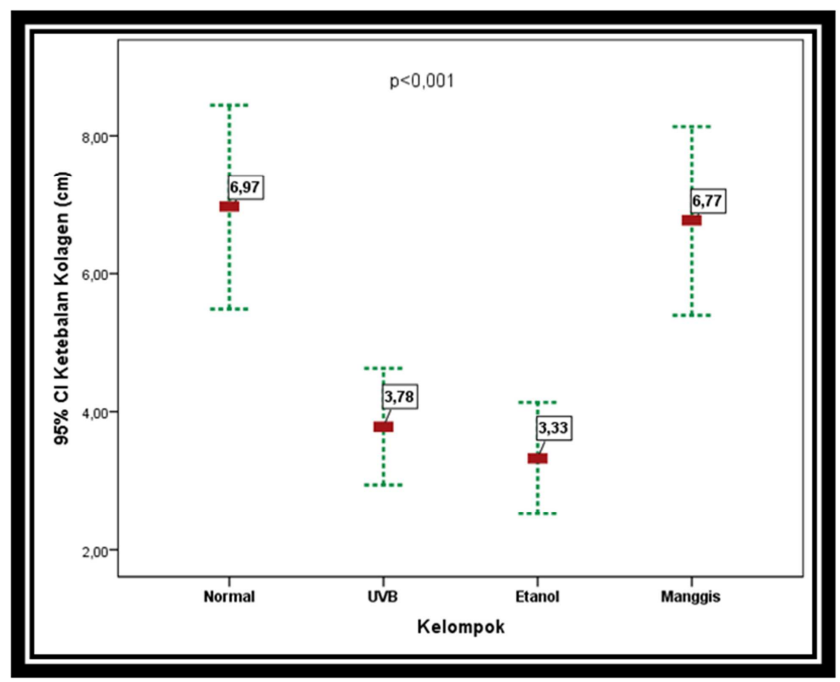

Figure 1. Comparison of the thickness of the collagen.

In Table 2 shows the thickness of the collagen in normal group was significantly higher than UVB group and ethanol. The thickness of the collagen in mangosteen group was significantly higher than UVB group and ethanol. No significant differences between groups of collagen thickness of mangosteen with the normal group. No significant differences between groups of collagen thickness of UVB with ethanol group. 
Table 2. Multiple Comparisons.

\begin{tabular}{llll}
\hline (I) Group & (J) Group & Mean Difference (I-J) & P \\
\hline \multirow{3}{*}{ Normal } & UVB & 3,18 & 0,000 \\
& Etanol & 3,64 & 0,000 \\
& Manggis & 0,20 & 1,000 \\
& Normal & $-3,18$ & 0,000 \\
UVB & Etanol & 0,46 & 1,000 \\
& Manggis & $-2,98$ & 0,001 \\
& Normal & $-3,64$ & 0,000 \\
Etanol & UVB & $-0,46$ & 1,000 \\
& Manggis & $-3,44$ & 0,000 \\
& Normal & $-0,20$ & 1,000 \\
\multirow{2}{*}{ Manggis } & UVB & 2,98 & 0,001 \\
& Etanol & 3,44 & 0,000 \\
\hline
\end{tabular}

Post-hoc test (Bonferroni)
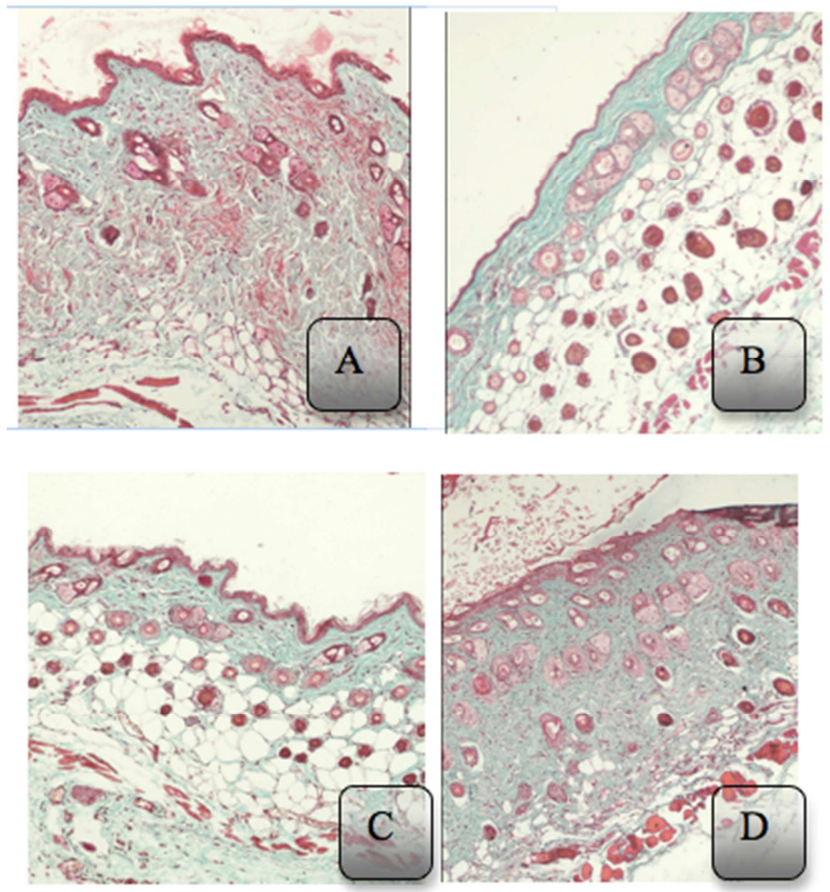

Figure 2. Histopathology thickness of collagen; A (Normal), B (UV), C (Ethanol), D (Mangosteen); Masson's Thrichrome staining; magnification $100 X$.

\subsection{Collagen Density}

There are significant differences in collagen density score by the sample group $(\mathrm{p}<0.001)$ (Table 3 and Figure 3 )

Table 3. Comparison of Collagen Density Score.

\begin{tabular}{lllllll}
\hline Group & Minimum & Maximum & Mean & Median & SD & p \\
\hline Normal & 4,00 & 4,00 & 4,00 & 4,00 & 0,00 & \\
UVB & 2,33 & 3,33 & 2,83 & 2,83 & 0,35 & \\
Etanol & 2,00 & 3,67 & 3,06 & 3,33 & 0,61 & 0,000 \\
Manggis & 3,67 & 4,00 & 3,89 & 4,00 & 0,17 & \\
\hline
\end{tabular}

Kruskal-Wallis

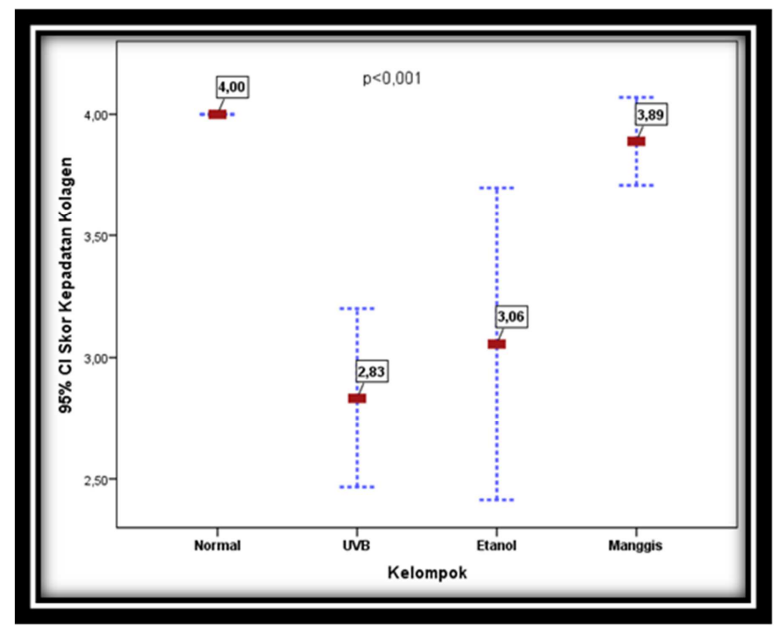

Figure 3. Comparison of the density of the collagen.

In Table 4 shows collagen density scores of normal is significantly higher than UVB and ethanol group. The mangosteen group significantly higher than UVB and ethanol group. No significant differences between mangosteen with the normal group. No significant differences between UVB with ethanol group.

Table 4. Multiple Comparisons.

\begin{tabular}{llll}
\hline (I) Group & (J) Group & Mean Difference (I-J) & P \\
\hline \multirow{3}{*}{ Normal } & UVB & 1,17 & 0,000 \\
& Etanol & 0,94 & 0,001 \\
& Manggis & 0,11 & 1,000 \\
& Normal & $-1,17$ & 0,000 \\
UVB & Etanol & $-0,22$ & 1,000 \\
& Manggis & $-1,06$ & 0,000 \\
& Normal & $-0,94$ & 0,001 \\
Etanol & UVB & 0,22 & 1,000 \\
& Manggis & $-0,83$ & 0,004 \\
& Normal & $-0,11$ & 1,000 \\
Manggis & UVB & 1,06 & 0,000 \\
& Etanol & 0,83 & 0,004 \\
\hline
\end{tabular}

Post-hoc test (Bonferroni)
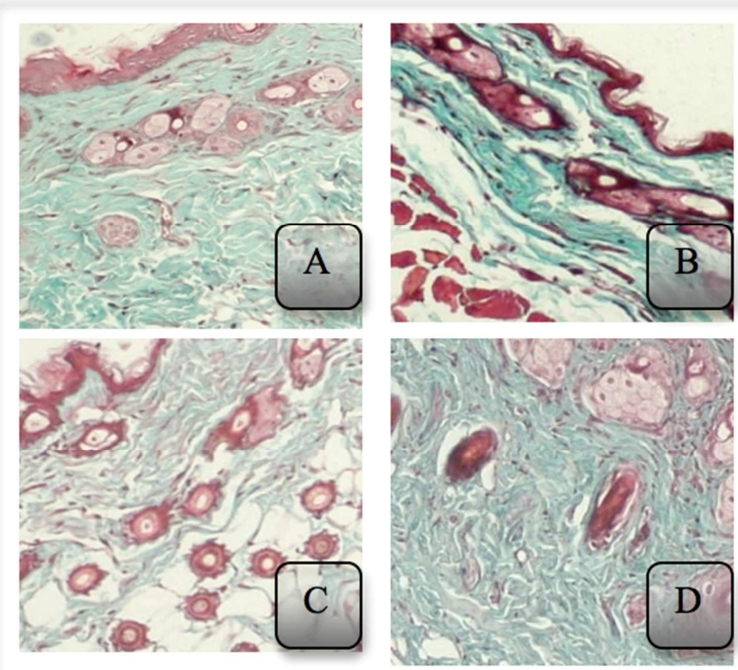

Figure 4. Density Collagen; $A$ (Normal), $B$ (UV), $C$ (Ethanol), $D$ (Mangosteen); Masson's Thrichrome staining. Magnification 400X. 


\section{Discussion}

Collagen is the primary polypeptide / protein in the extracellular which is found in almost all organs of the human body. There are as many as 21 types of collagen, the number and type vary depending on a variety of human organs. [8] It has been widely demonstrated that the type of collagen that dominates the skin is collagen-1 and collagen- 3 on mechanical defense function, but the type of collagen that also exists on the skin, such as collagen-5, collagen-6, collagen-7, collagen-12 found in the minimum amount thought to have support the strength of skin, but the exact role is unclear. $[8,9]$

Ultraviolet B (UVB) is a spectrum of ultraviolet radiation with a wavelength of $290-320 \mathrm{~nm}$, and is the most effective ultraviolet penetrate the earth and cause damage to human skin. Damage caused by ultraviolet $\mathrm{B}$ is more to DNA damage cells that constitute the chromophore. UVB much absorbed into the epidermis and penetrate to the papillary dermis. The wavelength of the ultraviolet most effective cause erythema is $250-290 \mathrm{~nm}$ and the diminishing effect of erythema by increasing wavelength. Histopathologically on the other study with mice skin, $1-\mu \mathrm{m}$ single UVB irradiated with doses of 3 MED keratinocyte cell damage occurred at 30 minutes after exposure, and most obviously in 24 hours later. After 72 hours the cells damaged keratinocytes turned into parakeratotic and enlargement of endothelial cells occurs after 30 minutes to a maximum of 24 hours thereafter. [10]

Doses of UVB can cause damage to the collagen dermis (photoaging) in mice skin of several studies vary greatly. Vayalil et al., (2004), using a dose of $90 \mathrm{~mJ} / \mathrm{cm}^{2}$ for 2 months (total dose: $1440 \mathrm{~mJ} / \mathrm{cm}^{2}$ ) with a dose every other day. [11] Ericson., (2014), with exposure to UVB three times a week for 1 month with a total dose of $840 \mathrm{~mJ} / \mathrm{cm}^{2}$. [12] Research in Makassar using UVB and mice as experimental animals, among others; Djawad K (2008), using the exposure to UVB $343 \mathrm{~mJ} / \mathrm{cm}^{2}$ three times a week. [13] Waspodo E (2012), exposure to UVB $343 \mathrm{~mJ} / \mathrm{cm}^{2}$ three times a week, [14] Adriani A (2014), exposure to UVB $450 \mathrm{~mJ} / \mathrm{cm}^{2}$ three times a week. Referring to the above study, a dose of UVB used in this study of $450 \mathrm{~mJ} / \mathrm{cm}^{2}$ three times a week for 4 weeks. [15]

Before the irradiation with UVB, mice were shaved in the back area and reshave before the next irradiation. These actions were taken to reduce the influence of hair against transmission of UVB.

This research uses healthy and normal mice, albino strains 6-9 weeks of age and weigh 20-30 grams. The using mice as object because mice is a mammalian vertebrate, and its structure similar to human skin. It has similarities with humans as young adults who have not experienced the intrinsic aging. An albino mice strain has no pigment included in the hair follicle. Vayalil et al., (2004) in his research on green tea and its effects in preventing the influence of ultraviolet exposure, using SKH-1 hairless mice. Hairless mice is ideal for research that requires treatment by exposure of the skin because it is more practical and no longer need to do the shaving. [11] The strain of mice without hair yet can be found in Indonesia.

The thickness and density of collagen in this study was significant difference according to the sample group ( $p$ $<0.001$ ), where the results of statistical tests show the thickness and density of collagen in mangosteen group was significantly higher than UVB and ethanol groups and did not differ with the normal group.

An experimental study conducted by Kim S.Y. et al., (2004) using mice strain balb/c by UVB with a total dose of $600 \mathrm{~mJ} / \mathrm{cm}^{2}$ and is given three times a week for 4 weeks will cause photoaging of the skin. [16] Wahyuningsih (2010) found significant damage to the collagen in the skin (photoaging) obtained with a total dose of UVB at 840 $\mathrm{mJ} / \mathrm{cm}^{2}$ three times a week for 4 weeks. [17]

UV radiation has many negative effects on the skin, either directly or indirectly. It is estimated that approximately $50 \%$ of damage caused by UV occurs due to the formation of free radicals, while the direct cellular damage and other mechanisms is a cause for the rest. Damage to the skin dermis extracellular matrix of UV essentially mediated cellular and molecular mechanisms involved include cell surface receptors, protein kinase signal transduction pathways, transcription factor, matrix metalloproteinase (MMP). [18] The main factors were allegedly responsible for the damage to the collagen in photoaging case is the presence of free radicals triggered by ultraviolet $B$ which cause damage mainly in extracellular matrix of collagen breakdown. [9]

UV radiation may activate the growth factor receptor cytokines (growth factors), on the surface of keratinocytes in the epidermis and in dermal fibroblast cells. It is estimated that about 15 minutes after UV exposure, there will be activation of the receptor for epidermal growth factor (IL-1 and TNF- $\alpha$ ) in keratinocytes and fibroblasts. Activation of this receptor induces intracellular signaling such as MAP kinase complex which then activates nuclear transcription factor activator protein-one (AP-1). [19] ROS is as oxidant and through the oxidation process will reduce proteintyrosine phosphatase enzyme. The decline of this enzyme will cause up-regulation of growth factor receptors and ultimately activates AP-1. [18]

Free radicals cause damage and the relative decline of both enzymatic and nonenzimatic antioxidants which are a defense system of the skin and ultimately can lead to various disorders such as skin cancer, suppress the immune system including premature skin aging. [20, 21] Radical oxygen species is believed to activate signal transduction pathways cytoplasm in skin fibroblasts which would affect the growth, differentiation and aging and degradation of connective tissue and can cause permanent genetic abnormalities. [21]

Expression of c-jun component of AP-1 excessive fibroblast culture results can reduce the number of collagen-1 expression. In the dermis and epidermis, AP-1 induces expression of MMP collagenase (MMP-1), stromelysin-1 (MMP-3) and 92-kd gelatinase B (MMP-9) that destroy collagen and other proteins that make up the extracellular matrix of the dermis. AP-1 can suppress gene expression of 
procollagen-1, procollagen-3 and TGF $\beta$ dermal fibroblasts resulting in decreased synthesis of collagen. [4, 8, 22]

Antioxidants are molecules that inhibit the oxidation process of oxidant molecules. Oxidation is a chemical reaction that transfers electrons or hydrogen from one substance to oxidant agents. Antioxidants serve capture compounds and prevent a chain reaction. This mechanism works by binding the metal, transition triggers ROS and then set it aside. Antioxidants are included in the secondary antioxidants are: Vitamin E, Vitamin $\mathrm{C}$, beta carotene, uric acid, bilirubin, transferrin, lactoferrin, ceruloplasmin, xhantone and albumin. [23]

The study conducted by Ericson (2014) using a solutio of mangosteen pericarp extract with a concentration of $95 \%$ showed significant differences in MMP - 1 and the amount of collagen. [12] In the experiment of making extracts of mangosteen pericarp in the laboratory of Pharmacognosy, University of Hasanuddin, the maximum dose that can be made for drops is a concentration of $50 \%$ so that the mangosteenpericarp extract doses used in this study was 2 $\mathrm{mg} / \mathrm{g}$ BB Weight mice.

Mangosteen pericarp oxidises clear resin that is rich in xanthones [6] Extraction of mangosteen peel found to contain $95 \%$ Xanthone, besides that it obtained also contains isoflavones, tannins and flavonoids. [7] In addition mangosteen pericarp also contains anthocyanins. [24] Xanthone is a yellow pigment found in some families of higher plants, fungi, moss plants. Mangostin is a major Xanthone element, and is found in mangosteen. [25] Xanthone are polyphenolic compounds with a chemical structure containing tricyclic aromatic ring. This structure has a biological activity such as antioxidants, antinflamatory, antibacterial, anticancer. [26] The antioxidant activity of the skin of the mangosteen is very strong as a radical scavenging. [27] So that the antioxidant properties of mangosteen peel can inhibit the formation of ROS, and further inhibits the destruction of collagen by exposure to UVB and increases collagen dermis.

From this study it can be concluded that (1) the mangosteen pericarp extract concentration of 50\% (a dose of $2 \mathrm{mg} / \mathrm{g}$ weight mice) can increase the thickness and density of collagen in the skin of mice was exposed to UVB. (2) it is needed to do in the next research on the role of the mangosteen pericarp extracts with varying concentrations and dosage due to the corelation of the thickness and density of collagen. (3) for the next research is interesting to study about mangosteen pericarp extract role in inhibiting of other sign of aging process / photoaging.

\section{References}

[1] Lim HW. Photoprotection. In: Goldsmith LA, Katz SI, Gilchrest BA, Paller AS, Leffell DJ, Wolff K, editors. Fitzpatrick's Dermatology in General Medicine. $8^{\text {th }}$ ed. USA: Mc Graw Hill; 2012. p. 2707-13.

[2] Adriani A. Analisis Ekspresi 8-OHDG, PCNA, dan
Hiperplasia Epidermis Pada Kulit Mencit yang Mendapat Ekstrak Kakao Topikal dan Paparan UVB [Disertasi]. Makassar: Hasanuddin; 2014.

[3] Diegelmann RF. Collagen Metabolism 200818 July 2015 [cited $2015 \quad 15$ August]. Available from: http:/http://www.medscape.com/viewarticle/423231.

[4] Fisher GJ, Choi HC, Batta C, Sorgo Z, Shao, Datta ZQ, et al. Ultraviolet Irradiation Increase Matrix Metalloproteinase-8 Protein in Human Skin In Vitro. J Invest Dermatol. 2007: 117-26.

[5] Hanggono T. Biomolekular mechanism of antioxidant activity on aging proccess2004 [cited 201510 August]. Available from:

http://pustaka.unpad.ac.id/wpcontent/uploads/2013/10/biomol ecular_mechanism.pdf.

[6] Akao Y, Nakagawa Y, Linuma M, Nozawa Y. Anti-Cancer Effects of Xanthones from Pericarps of Mangosteen. Int J Mol Sci. 2008; 9: 355-70

[7] Priya V, Jainu M, Mohan SK, Saraswati P, Gopan CS. Antimicrobial activity of pericarp extract of garcinia mangostana. IJPSR. 2010; 1(8): 279-81.

[8] Rhein LD, Santiago JM. Matrix metallo proteinase, Fibrosis, and Regulation by transforming Growth Factor Beta: A new Frontier in Wrinkle Repair. In: Rhein LD, Fluhr JM, editors. Current and Future Therapeutic Strategis. $1^{\text {st }}$ ed. USA: Allu Red Bussiness Media; 2010. p. 26-81.

[9] Uito J, Chu M, Gallo R, Eizen AZ. Collagen, Elastic fibers and extracellular matrix of the dermis. In: Goldsmith LA, Katz SI, Gilchrest BA, Paller AS, Leffell DJ, Wolff K, editors. Fitzpatrick's Dermatology in General Medicine. USA: Mc Graw Hill; 2008. p. 2560-82.

[10] Gilchrest BA. Skin Aging. Germany: Springer - Verlag Berlin Heidelberg; 2006.

[11] Vayalil PK, Mitta A, Hara Y, Elmets CA, Katiyar SK. Green tea Polyphenol Prevent Ultraviolet Light Induce Oxidative Damage and Matrix Metalloproteinase Expression in Mouse Skin. J Invest Dermatol. 2004; 122: 1480-7.

[12] Ericson YL. Pemberian Solutio Ekstrak Etanol Kulit Manggis (Garcinia Mangostana) Meningkatkan Jumlah Kolagen Dermis dan Menurunkan Ekspresi Matriks Metalloproteinase1 Pada Kulit Mencit Yang Dipapar UVB [Thesis]. Denpasar: Udayana; 2014.

[13] Djawad K. Efek fotoprotektif kurkumin terhadap ekspresi CPD, 8-OHdG, apoptosis dan hiperplasia epidermis [Disertasi]. Makassar: Hasanuddin; 2008.

[14] Waspodo N. Peran ekstrak biji kakao terhadap penuaan dini kulit setelah pajanan sinar ultraviolet B (ekspresi transforming growth factor B dan matriks metalloproteinase-1 [Thesis]. Makassar: Hasanuddin; 2012.

[15] Adriani A. Analisis Ekspresi 8-OHdG, PCNA, dan Hiperplasia Epidermis pada kulit mencit yang mendapat ekstrak kakao topikal dan paparan UVB [Disertasi]. Makassar: Hasanuddin; 2014.

[16] Kim SY, Kim SJ, Lee JY, Kim WG, Park WS, Sim YC, et al. Protective effects of dietary soy isoflavones againts UVInduced Skin Aging in Hairless Mouse model. JACN. 2004; 23: $157-62$. 
[17] Wahyuningsih KA. Pemberian Asthaxantine Topikal Menghambat Penuaan Dini Kulit akibat Pajanan Sinar Ultraviolet B dengan Memberikan Efek Proteksi Terhadap Kolagen pada Mencit (Mus Musculus). [Thesis]. Denpasar: Udayana; 2010

[18] Rabe JH, Mamelak AJ, McElgunn PJS, Morison WL. Photoaging mechanism and repair. J Am Acad of Dermatol. 2006; 55: 1-19.

[19] Rigel DS, Weiss RA, Lim HW, Dover JS. Photoaging. In: Dekker M, Gilchrest BA, Paller AS, Leffel DJ, editors. Fitzpatrick's Dermatology in General Medicine. 6th ed. Newyork: Mc Graw Hill; 2004. p. 517-41.

[20] Kochevar IE, Taylor CR. Photophysics, Photochemistry and Photobiology. In: Feedberg IM, Eisen AZ, Wolff K, Austen KF, Goldsmith LA, Katz Si, editors. Fitzpatrick's dermatology in general medicine. New York: Mc Graw Hill; 2008. p. 126775 .

[21] Chen L, Hu JY, Wang SQ. The Role Antioxidant in Photoprotection: a critical review. J Am Acad Dermatol. 2012; 43: 112-7.

[22] Fisher GJ, Wang ZQ, Datta SC, Varani J, Kang S. Pathophysiology of Premature Skin Aging. N Eng J Med. 2001; 337: 1419-29.
[23] McDaniel CF. Understanding antioxidant 2007 [cited 201513 August]. Available from: http: //www fisherinstitute.org.livepages antioxidant.

[24] Pradipta IS, Nikodemus TW, Susilawati Y. Isolasi dan Identifikasi Senyawa Golongan Xanton dari Kulit Buah Manggis (Garcinia mangostana L). Yogyakarta: Universitas Islam Indonesia; 2009.

[25] Peres V, Naem TJ, deoliviera FF. Antioxidant and antimicrobial activities of crude extracts from mangosteen (Garcinia mangostana L.) parts and some essential oils. 2000 [cited 201515 August]. Available from: http://www. International Food Research Journal 17: 583-589 (2010).

[26] Nakagawa $\mathrm{Y}$, Linuma M, Naoe T, Nozawa Y, Akao Y. Characterized mechanism of alpha-mangostin induced cell death: caspase independent apoptosis with release of endonuclease- $\mathrm{G}$ from mitochondria and increased miR-143 expression in human colorectal cancer DLD-1 cells.. J Bio Med Chem. 2007; 15(16): 5620-8.

[27] IPB. Evaluasi biomassa, kadar dan profil derivates Xanthone serta potensi antioksidan kulit buah manggis (garcinia mangostana 1). Dari beberapa tipe Agroekologi sentra produksi manggis. 2009 [cited 201510 August]. Available from: http: //www.search-document.com/pdf/7/10/kandungankulit-manggis.html\#. 